\title{
Nagy szilárdságú acéllemezek és hegesztett terítékek alakítási jellegzetességei
}

\section{Some Formability Aspects of High Strength Steel and of Consisting Tailor Welded Blanks}

\author{
Béres Gábor J., ${ }^{1}$ Végvári Ferenc, ${ }^{2}$ Danyi József ${ }^{3}$ \\ Neumann János Egyetem, GAMF Müszaki és Informatikai Kar, Innovatív Jármüvek és Anyagok Tanszék, \\ Kecskemét, Magyarország \\ ${ }^{1}$ beres.gabor@gamf.uni-neumann.hu \\ 2 vegvari.ferenc@gamf.uni-neumann.hu \\ ${ }^{3}$ danyi.jozsef@gamf.uni-neumann.hu
}

\begin{abstract}
In recent years, the demand for a reduction in pollutant emission has become extremely important in the vehicle industry. It can be achieved through fuel consumption reduction, which is a direct function of the vehicle's weight. Nowadays weight is widely controlled by the use of advanced- and ultra-high strength steels (AHSS and UHSS) in vehicle body construction. With the application of such steel sheets as chassis elements, crashworthiness can be maintained next to reduced sheet thicknesses, too. In this paper, the deep-drawability and springback after V-die bending is monitored for three types of AHSS grades, namely DP600, DP800 and DP1000 materials. The investigations are extended to tailor welded blanks (TWBs), made by the aforementioned steels coupled with a cold rolled steel sheet (DC04). Our results show that deep-drawability reduces with both the increase in strength and the increase in strength difference between the components in the TWBs. Furthermore, the higher strength is shown to cause higher spring-back. The TWBs have unique springback behavior around the weld line.
\end{abstract}

Keywords: high strength steels, tailor welded blanks, deep-drawability, springback.

\section{Összefoglalás}

Az utóbbi években rendkívüli módon megnőtt a járművek tömegének, üzemanyag-fogyasztásának és károsanyag-kibocsátásának csökkentési igénye a járműiparban. E törekvések többek között az újonnan kifejlesztett nagy és különlegesen nagy szilárdságú acéllemezeknek a járműkarosszéria-építésben történő alkalmazása révén jutnak érvényre. Ezeknek az anyagoknak a felhasználásával ugyanis a jármű vezetőjének és utasainak biztonsága csökkentett keresztmetszetek (lemezvastagságok) mellett is megfelelő szintű maradhat. A cikkben három különböző, DP600, DP800 és DP1000 típusú, nagy szilárdságú lemezanyag mélyhúzhatóságának és alakítás utáni visszarugózásának kísérleti vizsgálati eredményeire világítunk rá. A vizsgálatainkat különböző terítékekből méretre szabott, hegesztett lemezekre (Tailor Welded Blanks) is kiterjesztettük, hogy ezen újszerű terítéktípusok viselkedéséről is képet kapjunk. Eredményeinkből az látható, hogy a mélyhúzhatóság, a terítékek szilárdságának növekedésével, továbbá méretre szabott lemezek esetén a terítéket alkotó lemezszegmensek közötti szilárdságkülönbség növekedésével csökken. A hajlítás utáni viselkedés terén a nagyobb szilárdságú lemezanyagok nagyobb visszarugózást is mutattak, míg a hegesztett terítékeknél egy átmeneti visszarugózási szög érték volt tapasztalható a hegesztési varrat környezetében.

Kulcsszavak: nagy szilárdságú lemezanyagok, hegesztett lemezek, hajlítás, mélyhúzás. 


\section{Bevezetés}

Bár a nagy szilárdságú acéllemezek önmagukban is elterjedten használatosak a karosszériaépítésben, ma már egyre gyakoribb, hogy egy alkatrészt különböző szilárdságú vagy különböző vastagságú, esetleg eltérő bevonatú lemezdarabokból, előre összehegesztett terítékből gyártanak. Ennek oka, hogy az ún. anyagidealizált tervezési szemléletben (amely életre hívta az angolul tailored blanksnek, magyarul méretre szabott elemeknek nevezett terítékeknek az egyre terjedő alkalmazását) az anyagválasztás elve abban rejlik, hogy az egyes alkatrészek anyagát az elhelyezkedésük által meghatározott rendeltetés szabja meg elsősorban, és ehhez igazítják a szükséges gyártási és szerelési technológiákat. Így, a hegesztett terítékek alkalmazásával egy alkatrészen belül is teljesülni képes a legmegfelelőbb anyagoknak a legmegfelelőbb helyre történő pozicionálása, ami nagy előrelépést jelent a járművek vázszerkezetének fejlesztésében [1]. Az egy alkatrészen belüli különböző tulajdonságok miatt azonban a méretpontos gyártás a korábbinál nagyobb problémát jelent.

A nagy szilárdságú lemezanyagok megjelenése alapjában véve is új alakítástechnológiai nehézségeket jelentett, mivel azok alakíthatósága, visszarugózása jelentősen eltér a korábban megszokott lemezanyagok hasonló jellemzőitől. $\mathrm{Az}$ 1. ábrán látható, hogy az acélok szilárdságának növelése alakíthatóságuk csökkenésével jár [2]. Egyetemünk elődjének GAMF Karán, a Miskolci Egyetem Mechanikai Technológiai Tanszékével közösen, pályázat keretében foglalkoztunk a nagy szilárdságú és hegesztett lemezek különböző alakíthatósági és egyesíthetőségi vizsgálataival (pl. hajlítás utáni visszarugózásukkal, mélyhúzhatóságukkal, sajtoló, klincselt és ponthegesztett

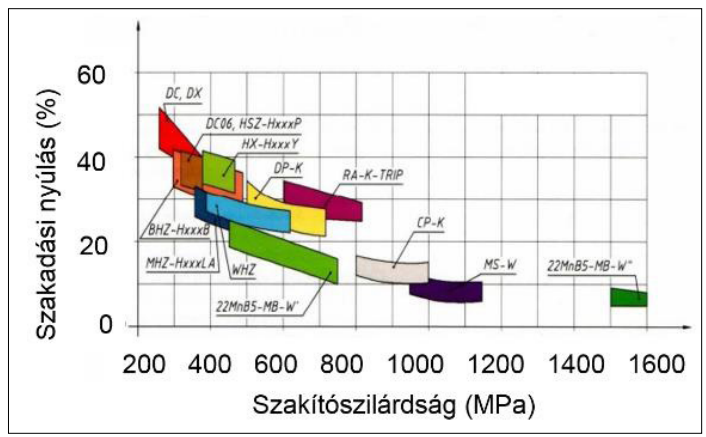

1. ábra. A hagyományos és új lemezanyagok szilárdságának és alakíthatóságának kapcsolata kötések kialakításával, illetve nagy energiasebességű alakításokkal - High Energy Rate Forming). Jelen cikkünkben három különböző típusú, nagy szilárdságú lemezanyag és egy jól alakítható lágy lemezanyag, illetve az ezekből készített hegesztett terítékek hajlításánál fellépő visszarugózásnak, továbbá a mélyhúzhatóságnak a kérdésköreibe nyújtunk betekintést.

\section{A vizsgált anyagok jellemzői}

A kutatásainkhoz $1 \mathrm{~mm}$-es kiinduló lemezvastagságú (t), kereskedelmi forgalomban kapható DC04, illetve Docol DP600, DP800 és DP1000 típusú, bevonat nélküli lemezanyagokat használtunk fel, amelyek közül utóbbi három a fejlett nagy szilárdságú acélok csoportjába tartozik. Ezekben az anyagokban a DP rövidítés a kettős fázisú (helyesebben kettős szövetelemű) szövetszerkezetükre utal, amelyet az interkritikus hőközből történő gyorshűtéssel állítanak elő a gyártók. Az így kapott ferrit-martenzites szövetszerkezet a növelt szilárdság mellett is biztosít bizonyos mértékű alakíthatóságot [3]. A DC04 hidegen hengerelt, mélyhúzási célú, tisztán ferrites, lágy lemezanyag [4]. A felhasznált lemezek alapvető mechanikai tulajdonságjellemzőit (folyáshatár, szakítószilárdság, egyenletes és teljes nyúlás) az MSZ EN ISO 6892 szerinti szakítóvizsgálatokkal határoztuk meg, anyagonként három párhuzamos mérésből. A kapott középértékeket az 1. táblázatban foglaltuk össze.

1. táblázat. Az alkalmazott anyagok alapvető mechanikai tulajdonságai

\begin{tabular}{|l|c|c|c|c|}
\hline & $\begin{array}{c}\mathbf{R}_{\mathrm{p} 0,2} \\
\text { (MPa) }\end{array}$ & $\begin{array}{c}\mathbf{R}_{\mathbf{m}} \\
\text { (MPa) }\end{array}$ & $\begin{array}{c}\mathbf{A}_{\mathrm{g}} \\
\mathbf{( \% )}\end{array}$ & $\begin{array}{c}\mathbf{A}_{\mathbf{8 0}} \\
\mathbf{( \% )}\end{array}$ \\
\hline DC04 & 238 & 336 & 22,6 & 37,9 \\
\hline DP600 & 444 & 656 & 13,6 & 20,6 \\
\hline DP800 & 570 & 789 & 10,8 & 16,0 \\
\hline DP1000 & 758 & 1099 & 7,0 & 10,6 \\
\hline
\end{tabular}

\section{A hajlítás utáni visszarugózás vizsgá- lata}

Hajlításnál, a hajlítóerő vagy nyomaték megszűnésekor a lemez kinyílik, a darab hajlítási szöge nagyobb lesz, mint a szerszám zárásakor volt. Ennek egyik oka, hogy a darabon belüli semleges szál környezetében mindig marad egy, csak rugalmasan alakváltozó réteg, amelynek nyomatéka igyekszik visszaalakítani a lemezt a kiinduló állapotába. A másik ok az, hogy a képlékenyen deformálódott részek alakváltozása is rugalmas és 
képlékeny összetevőkből áll [5]. A visszarugózás mértékét így a lemezanyag szilárdsága, valamint a szerszámgeometriai jellemzők, pl. a hajlítási sugár és a lemezvastagság aránya, illetve a hajlítási szög befolyásolja döntő mértékben [6, 7, 8, 9]. E jellemzők együttes hatásának minél átfogóbb megfigyelése érdekében a különböző lemezanyagok hajlítási próbáit különböző szerszámozási körülmények között hajtottuk végre, állandó $20 \mathrm{~mm} /$ perc bélyegelmozdulási sebességgel, egy AMADA HFE 50-20 típusú CNC vezérlésű élhajlító gépen (2. ábra).

Az élhajlító (szabad hajlító) műveletek szerszámainak mühelyrajzát oldalnézetből szemlélteti a 3. ábra, amelyek zárásakor így $3 \mathrm{~mm}$-es és $5 \mathrm{~mm}$-es hajlítási sugárral $(r)$ is kísérletezni tudtunk. A kívánt $90^{\circ}$-os szögérték elérését a bélyeg elmozdulási úthosszának szabályozásával állítottuk be.

A 4. ábrán a vizsgált lemezek 3-as és 5-ös hajlítási sugár-lemezvastagság aránnyal ( $r / t$ viszony) történő hajlításakor mért visszarugózási szögek középértékei láthatók. A visszarugózási szögértékeket 15’ pontosságú mühelyszögmérővel mértük a terítékek oldalélén, háromszoros mérési ismét-

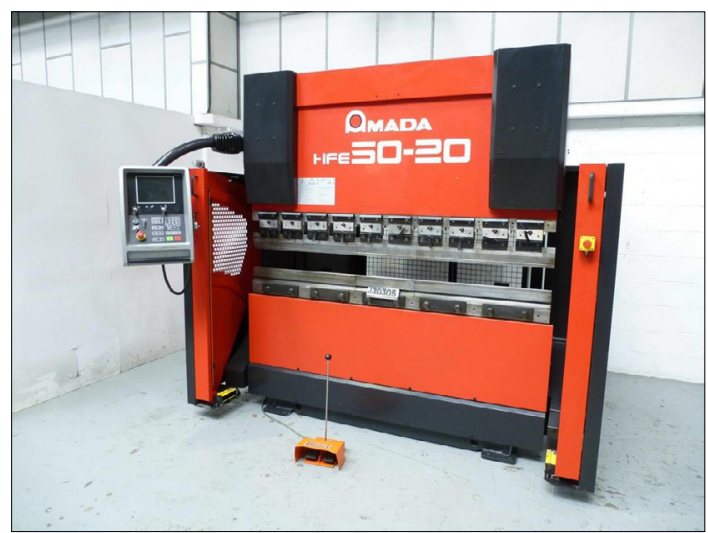

2. ábra. AMADA HFE 50-20 típusú, CNC-vezérlésü élhajlító gép.

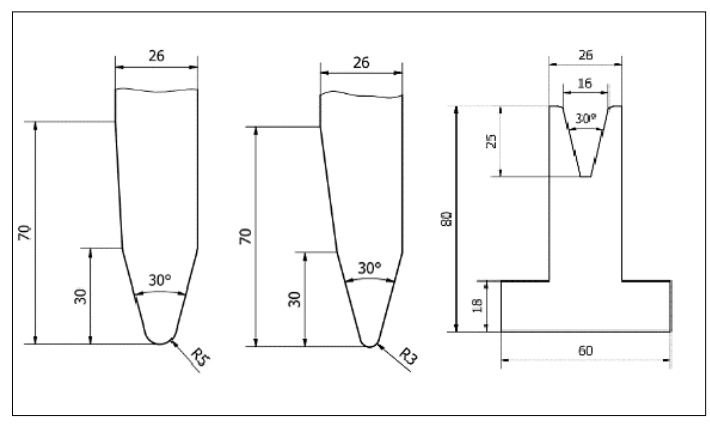

3. ábra. A szabadhajlítás szerszámai lésszám mellett, átlagosan $\pm 0,5^{\circ}$ eltéréssel. A terítékek mérete $120 \times 600 \mathrm{~mm}$ volt, a hajlítás tengelyvonala a hengerlési iránnyal párhuzamosan helyezkedett el. Az ábrán látható, hogy mind a szakítószilárdság, mind pedig az $r / t$ viszony növekedésével a lemezek visszarugózása $(\beta)$ jelentős mértékben növekszik.

A hegesztett lemezek esetében különböző szilárdságú elemekből állítottuk össze a terítékeket lézersugaras hegesztési eljárással, a Bay Zoltán Alkalmazott Kutatási Közhasznú Nonprofit Kft. Ipari Lézertechnológiai Laboratóriumában. A hegesztett kötések jellemzése a [10] cikkben olvasható. Az alkalmazott anyagpárosításoknál minden esetben a DC04-es anyagot kapcsoltuk egy-egy DP-s anyaghoz. Kísérleteink során azt vizsgáltuk, hogy a visszarugózás szempontjából miként hatnak egymásra az eltérő szilárdságú lemezrészek, illetve azt, hogy ez a kölcsönhatás hogyan alakul a hegesztési varrattól mért távolság függvényében. A vizsgált próbatestek kialakításának elve, sematikus ábrázolásban az 5. ábrán látható.

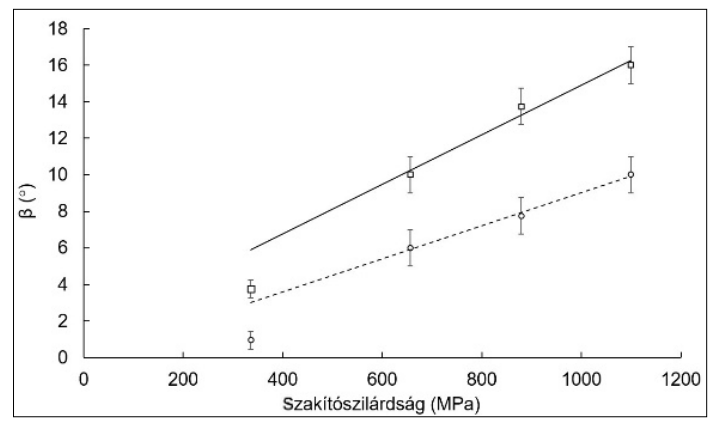

4. ábra. A vizsgált alaplemezek visszarugózási szögei

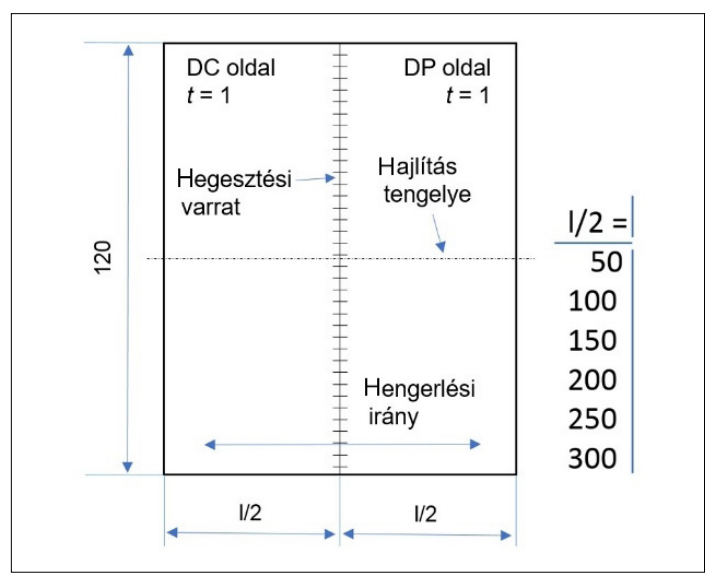

5. ábra. A hajlításhoz előkészített hegesztett lemezek sematikus ábrája. A méretek (mm)-ben értendők 
A 6. ábra diagramjain a hegesztett darabok oldalélein, azaz a különböző terítékméreteknek köszönhetően a hegesztési varrattól különböző távolságban mért visszarugózási szögek láthatók. A kísérleteket és a szögméréseket jelen esetben is háromszoros ismétlési gyakorisággal végeztük. A diagramokon az látható, hogy a hegesztési varrat környezetében egyik lemezszegmens sem gyakorolja az önmagában rá jellemző visszarugózási értéket, hanem ott egy átmeneti zóna alakul ki.

A hajlított darabok különböző részein mért eltérő visszarugózási szögek lényegében alakhibás darabokat jelentenek. Ez az alkatrészek beépítésekor, különösen automatizált szereléskor igen nagy problémát jelenthet.
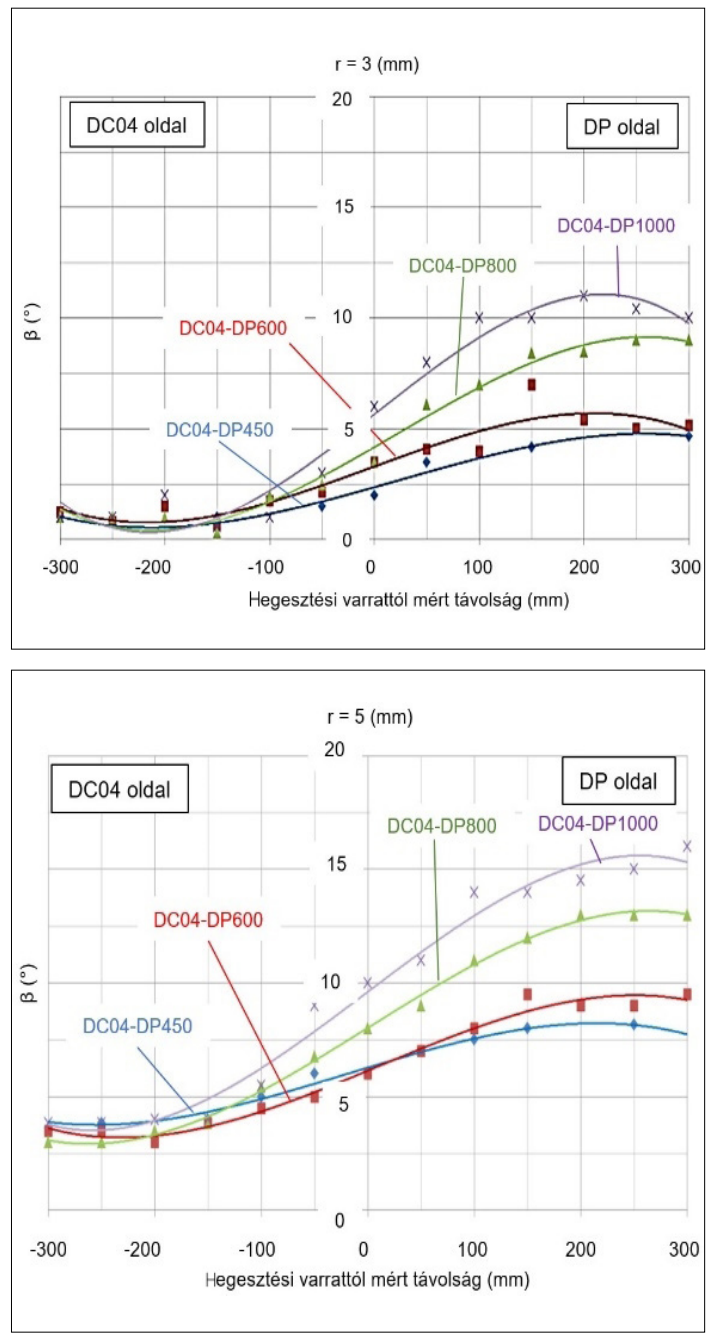

6. ábra. Hegesztett lemezeken mért visszarugózási szögek

\section{A mélyhúzhatósági vizsgálatok}

A lemezek mélyhúzhatósági vizsgálatát Erichsen 142-20 típusú, univerzális lemezvizsgáló gépen végeztük (7. ábra), a szabványos (MSZ 5731-68) Swift-féle vizsgálat szerszámozási feltételei mellett [11]. A szerszámok és a munkadarab elrendezését, illetve geometriáját a 8. ábra szemlélteti.

A vizsgálatokat $2 \mathrm{~mm}$-es lépésekben növekvő, $60,62,64 . .80 \mathrm{~mm}$ átmérőjü, ollón vágott, majd esztergált $( \pm 0,1 \mathrm{~mm}$ pontosságú) terítékek mélyhúzásával hajtottuk végre. Ebben a vizsgálati eljárásban a terítékek átmérőjét addig növeltük, amíg a csésze szakadása be nem következett. A vizsgálatokat ez esetben is háromszoros ismétlési gyakorisággal végeztük a Siebel egyenlet [12] által meghatározott ráncgátló erők mellett és a húzógyürü oldalán $0,012 \mathrm{~g} / \mathrm{cm}^{2}$ olajkenést alkalmazva (a [13] ajánlásai alapján). Néhány mélyhúzott csészéről készült fényképfelvétel a 9. ábrán látható.

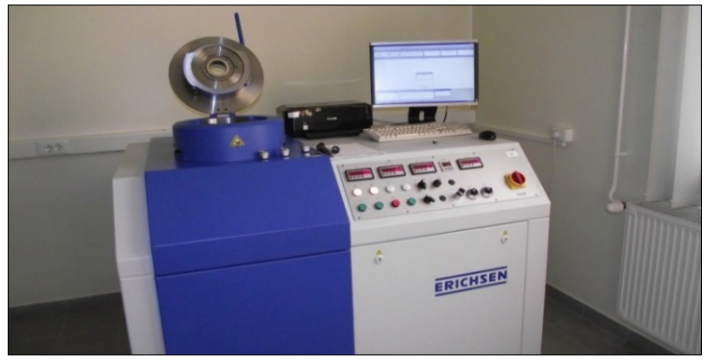

7. ábra. Univerzális lemezvizsgáló gép

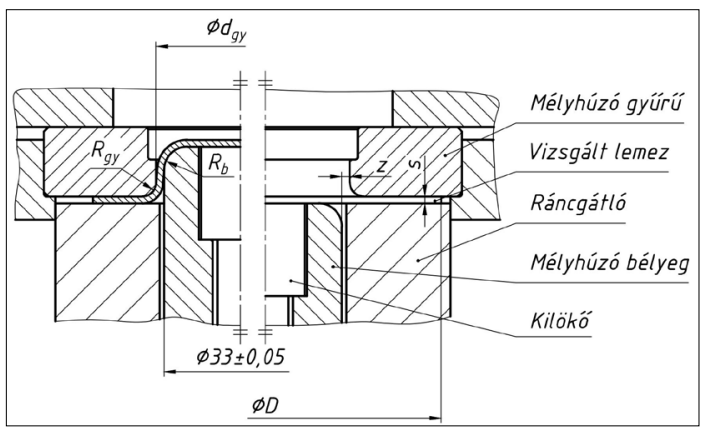

8. ábra. A csészehúzó szerszám vázlata

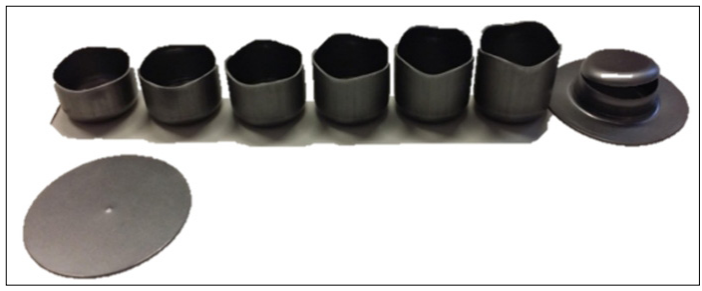

9. ábra. A vizsgált lemezekből mélyhúzott csészékről készült fényképfelvétel 
A különböző anyagok legnagyobb, még szakadás nélkül kihúzható terítékátmérőjét a $\mathbf{1 0}$. ábrán követhetjük nyomon. Látható, hogy a kisebb szilárdságú lemez határ húzási viszonya (limited drawing ratio - vagy $D / d$ ) nagyobb, mint a nagyobb szilárdságúaké. Természetesen a nagyobb szilárdságú lemezek tönkremenetelét okozó erő is sokkal nagyobb.

Közismert, hogy a mélyhúzás a lemezalakítási eljárások közül a legösszetettebb, az alakítási folyamat és a lemezanyag feszültségi és alakváltozási állapotát illetően egyaránt. A hegesztett, méretre szabott lemezek esete természetesen még bonyolultabb, hiszen az ilyen teríték kisebb szilárdságú része jobban nyúlik (ld. 10. ábra), jobban vékonyodik, mi több, azon az oldalon kisebb ráncgátló erő is elegendő/szükséges.

A csészehúzó próbákhoz a különböző szilárdságú lemezekből, lézersugaras hegesztési eljárással készítettünk terítékeket a 11. ábrán látható módon. Az eredményeket a korábban bemutatott módszerekkel megegyezően nyertük ez esetben is, és a hegesztett lemezek határ húzási viszonyát a húzóerő függvényében szemléltetjük a 12 ábrán. Látható, hogy a határ húzási viszonyt a hegesztett lemezek esetén nem önmagában csak a nagyobb vagy csak a kisebb szilárdságú lemezszegmens mélyhúzhatósága határozza meg, hanem a terítékrészek közötti szilárdságkülönbség is mérvadó az alakíthatóság szempontjából.

A hegesztett lemezekből történő mélyhúzás esetén a húzási művelet végét nem a részben kihúzott csésze fenékleszakadása, hanem a kisebb szilárdságú lemeznek a hegesztési varrat melletti elszakadása jelentette. A 13. ábrán DC04-DP1000 anyagpárosítású terítékből húzott csészék láthatók. Megfigyelhető a hegesztett terítékből húzott csészéken az is, hogy a csészék egyik felén intenzív fülesedés jelent meg. A kisebb szilárdságú lemez tehát anizotrop. Ennek a résznek a nagyobb nyúlását pedig az mutatja, hogy ezen az oldalon a csésze jóval magasabb, illetve hogy a kritikus elvékonyodás is itt következett be.

\section{Következtetések}

Kutatásunkban vizsgáltuk a fejlett, nagy szilárdságú lemezanyagok és a méretre szabott, hegesztett terítékek hajlítás utáni visszarugózását és mélyhúzhatóságát. Eredményeinkből az látható, hogy a visszarugózás az alkalmazott lemezanyag szilárdságával összhangban növekszik, míg a hegesztett terítékeknél a hegesztési vonal környezetében, egy átmeneti zónában, az egyik alkotó

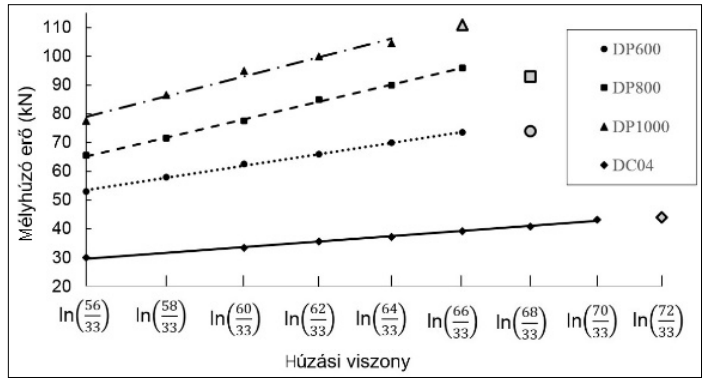

10. ábra. A különböző szilárdságú lemezek határ húzási értékei és a tönkremenetelt jelentő húzóerőértékek

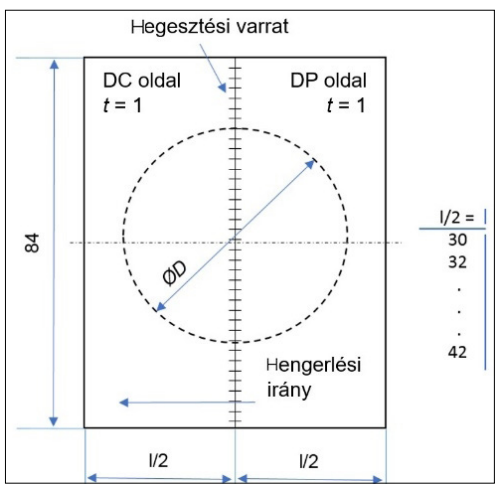

11. ábra. A terítékek kimunkálásának sematikus vázlata hegesztett lemezekből

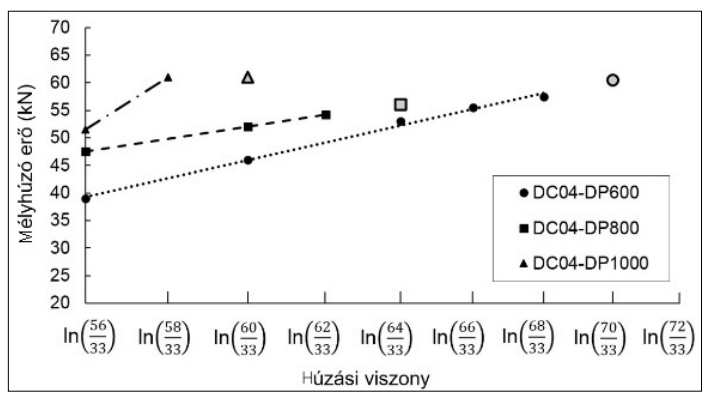

12. ábra. Hegesztett lemezek mélyhúzásának eredményei

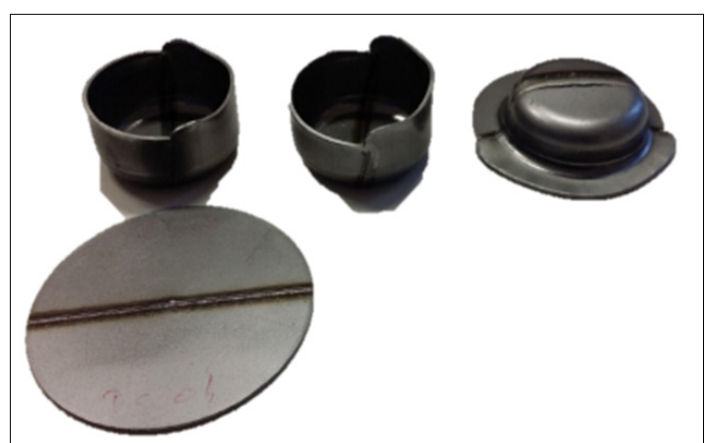

13. ábra. Hegesztett terítékekből mélyhúzott csészék fényképfelvétele 
anyagra sem jellemző visszarugózás mérhető. A mélyhúzhatóság terén a szilárdságnövekedés csökkenti a még szakadás nélkül kihúzható legnagyobb terítékátmérőt, illetve a hegesztett terítékek esetén, a lemezszegmensek közötti szilárdságkülönbség is behatárolja az alakíthatóságot.

\section{Szakirodalmi hivatkozások}

[1] Merklein M., Johannes M., Lechner M., Kuppert A.: A review on tailored blanks-Production, applications and evaluation. Journal of Materials Processing Technology, 214. (2014) 151-164. https://doi.org/10.1016/j.jmatprotec.2013.08.015

[2] Keeler S., Kimchi M.: Advanced High-Strength Steels Application Guidelines Version 6.0. 3S-Superior Stamping Solutions. LLC., WorldAutoSteel, 2017. 1-17.

[3] Kuziak R., Kawalla R., Waengler S.: Advanced high strength steels for automotive industry. Archives of Civil and Mechanical Engineering, 8/2. (2008) 103-117.

https://doi.org/10.1016/S1644-9665(12)60197-6
[4] Thyssenkrupp: Deep-drawing steels DD, DC and DX. Production information, 2018. 2-9.

[5] Danyi J., Végvári F.: Lemezmegmunkálás. Kecskeméti Főiskola, $1^{\text {st }}$ ed., Kecskemét, 2011. 97-104.

[6] Marciniak Z., Duncan J. L., Hu S. J.: Mechanics of Sheet Metal Forming. Butterworth-Heinemann, Oxford, 2002. 82-107.

[7] Lange K.: Handbook of Metal Forming. SME, Dearborn: Michigan, 1985. 19.1-19.23.

[8] Pearce R.: Sheet metal forming. Adam Hilger Series on new manufacturing processes and materials. IOP Publishing Ltd., 1991. 79-88.

[9] Metals Handbook Vol. 4. Forming. $8^{\text {th }}$ ed. American Society for Metals, Ohio: Metals Park, 1969.

[10] Kovács Zs. F., Béres G., Weltsch Z.: Autóipari DC és DP acélok lézersugaras hegeszthetöségének vizsgálata. Gradus, 4 (2017) 311-317.

[11] Swift H. W.: Drawing tests for sheet metal. Proceedings Institution of Automobile Engineers, 34:361 (1939)

[12] Siebel E., Beisswanger H.: Deep Drawing. Carl Hanser, München, 1955.

[13] Altan T., Tekkaya A. E.: Sheet Metal Forming Fundamentals. ASM International, 2012. 105-127. 